\title{
Arthur B. Davies, Sacramental Trees
}

\section{Emily Gephart}

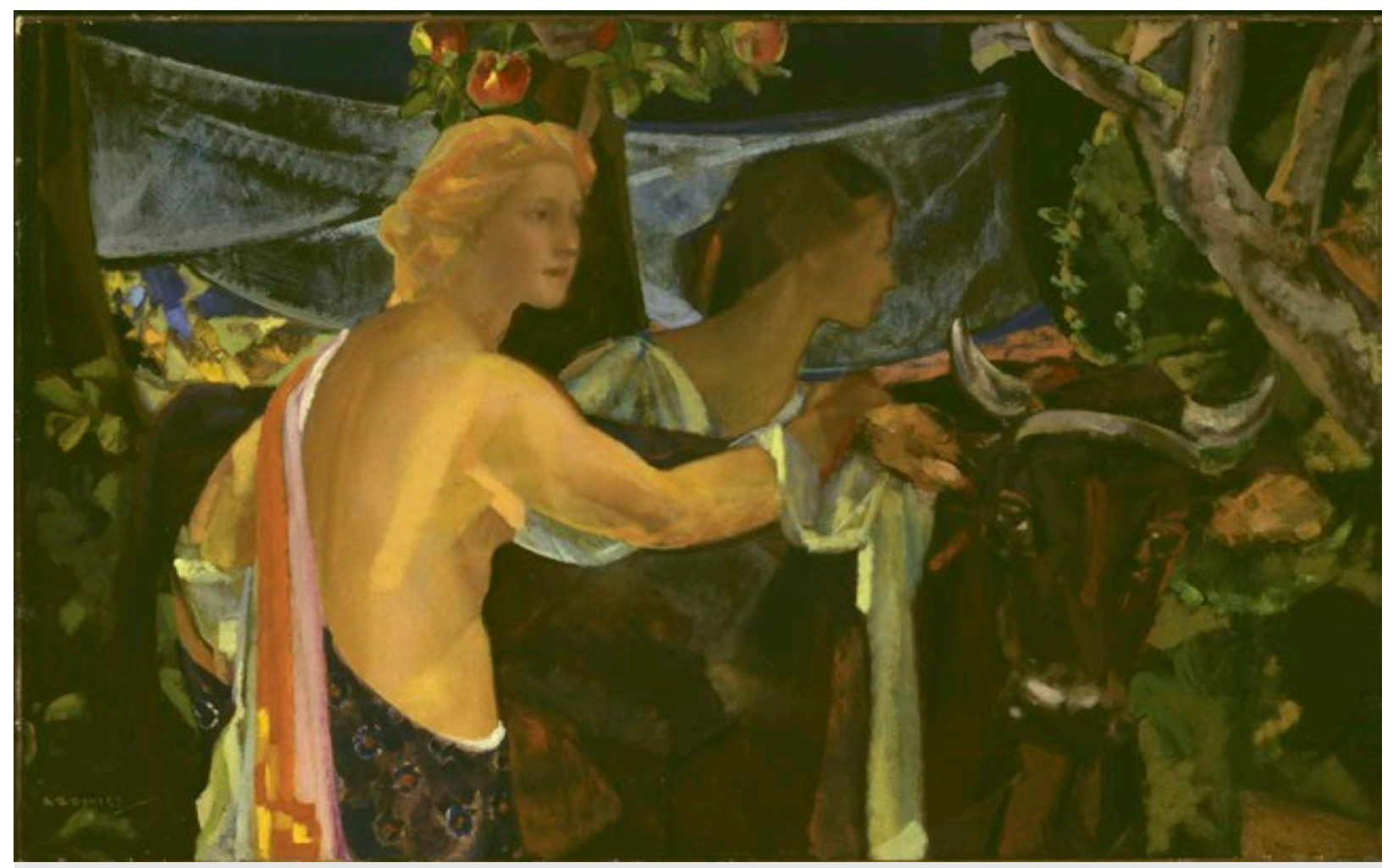

Arthur B. Davies, Sacramental Trees, ca. 1915

Two maidens, one bright and one shadowy, lead an ox through a curiously dense, shallow, and cubistically-fragmented woodland, heading (one presumes) through the titular sacramental trees and towards an uncertain destination. A gauzy curtain hangs in the background, blocking our visual access to a deeper view of the landscape. Ripe apples dangle from a branch immediately above the figures' heads, vines and vegetation form ceremonial garlands. It must be late summer: only that season could produce such lushness, demanding a ritual-a celebratory procession or perhaps even animal sacrifice-to ensure future years of plenty.

The female figures mirror one another from either side of the ox. Heads and shoulders incline in sympathy as both women lean to the right, their eyes on the unseen objective of their sacred mission. The fair-haired foreground figure, half-naked but draped in brightly-hued raiment, rests her hand reassuringly at the nape of the animal's neck. Our gaze is not met by either woman, but by the ox himself, who halts in the procession. His solemn, liquid stare connects with ours and reflects ancient placid wisdom, resignation to the inevitability of his indefinite fate. We are propelled onward by the rhythmically echoing bodies and intense focus of the maidens, absorbed in their task; but we pause, frozen in a moment of meditative contact between viewer and animal. Spatially, the painting offers neither the viewer nor figures anyplace else to "go." 
But, if in traditional Christian doctrines a sacrament is a sign of divine grace, what is the nature of the "sacrament" amongst the trees imagined by Arthur B. Davies? Raised in a stern Methodist family, Davies rejected most of this upbringing in his adult life, turning instead to secular concerns and new religions. Theosophy, philosophy, psychology, and spiritualism provided answers to the ontological and metaphysical questions that engaged him, as they did for many early-twentieth-century Americans. These explorations also nurtured his art. Davies was widely hailed as a dreamer and a painter whose images gave pictorial vision to nostalgic longing during years of great change, imagining transcendent, enduring truths towards which many yearned. His dreams showed a Golden Age-one located in the distant pagan past or equally plausibly in some remote, utopian future. Some art historians see this painting as a modern re-invention of "Europa and the Bull," but few signs indicate the impending violent abduction implied by such a mythological association. Rather, the sensuous image celebrates the bounties of nature, while the title invites the viewer to construct a ritual narrative, one that offers ambiguous conclusions.

Illustrated in a 1916 article published in Vanity Fair, the painting was lauded by critic Frederick James Gregg as a sign of "Modern Art's Revenge" on the philistines who decried the advances of avant-garde painting in America. ${ }^{2}$ In a previous essay celebrating Davies, Gregg had written "It is only necessary to look around to see that painting and sculpture are in a state of flux. All is disturbance. Change is everywhere. Something has happened. Something is happening. What that something is we cannot tell-as yet." 3 Davies's work, according to Gregg, exemplified this metamorphosis. But this particular painting seems perhaps an unusual choice to herald the controversial modernist cause: mingling abstraction with representation, it offers viewers a hybridized form whose spirit is harmonious, not contentious. Its formal qualities echo the ecumenical, pantheistic spiritualism Davies embraced, and was thus for Gregg, a suitably modern abstract "decoration"-the kind of painting that did not rely upon preestablished allegory or narrative to generate profound meaning.

Davies's scintillating cubo-futurist faceting, juxtaposed with the more mimetic treatment of human and animal bodies, renders the space neither wholly real nor unreal. His is a landscape of productive fantasy in which the viewer can become lost in contemplating the nature of transcendent sacramental grace, whatever regardless of the viewer's faith, and even in the midst of the modern revolutions transforming art, religion, and culture. Davies nonetheless grounded his experimental modernity by means of ancient roots. His Sacramental Trees tells an Arcadian, primeval and distantly remembered story, a dream about the vital, annual religious rituals of the pagan past, given modern relevance through unconventional form and enduring significance. Locking eyes with the ox, we are granted an awareness of life's evanescence and the certainty of fate and change, beyond the petty concerns of the immediate present.

(C) Emily W. Gephart 


\section{Citation Guide}

1. Emily Gephart, "Arthur B. Davies, Sacramental Trees," Object Narrative, in Conversations: An Online Journal of the Center for the Study of Material and Visual Cultures of Religion (2014), doi:10.22332/con.obj.2014.34

Gephart, Emily. "Arthur B. Davies, Sacramental Trees." Object Narrative. In Conversations: An Online Journal of the Center for the Study of Material and Visual Cultures of Religion (2014). doi:10.22332/con.obj.2014.34

\section{Notes}

1. "Europa and the Bull" refers to the Greco-Roman myth in which the god Zeus takes the form of a white bull in order to abduct Europa, an elite Phoenician woman.

2. Frederick James Gregg, "Modern Art's Revenge at San Francisco," Vanity Fair 5, (March, 1916), 51.

3. Frederick James Gregg, "What the New Art Has Done," Vanity Fair 4, (April, 1915), 30 .

\section{Yale}

Copyright 2016 Yale University All rights reserved. 